\title{
PERBANDINGAN PENGGUNAAN BATU PECAH DAERAH LINGKUT OKUT DAN DAERAH LAHAT SEBAGAI MATERIAL CAMPURAN ASPALT CONCRETE WEARING COURSE (AC WC) SEBAGAI PERKERASAN JALAN
}

\author{
Sephy Hendika Putra $\mathrm{M}^{1)}$, Derri Kurniawan ${ }^{2)}$ \\ ${ }_{1,2)}$ Dinas PUBMTR Kabupaten PALI
}

\begin{abstract}
ABSTRAK
Aspal beton merupakan salah satu jenis dari lapis perkerasan konstruksi perkerasan lentur. Campuran beton aspal tersebut terdiri atas agregat kasar, agregar halus, filler dan menggunakan aspal sebagai bahan pegikat. Filler yang biasa disebut juga bahan pengisi dapat diperoleh dari hasil pemecahan batuan secara alami maupun buatan. Dalam rangka memenuhi kebutuhan material untuk pembuatan aspal beton jenis SC-WC sumber material sangat menentukan. Sumber material yang digunakan untuk kebutuhan pembuatan aspal beton jenis AC WC ada yang didatangkan dari luar daerah sumsel yaitu batu pecah dari merak dan ada juga yang bersumber dari dalam sumatera sendiri yaitu batu ex Lahat kabupaten Lahat, ex Lingut kabupaten OKUT dan ex Martapura OKUS. Dalam penelitian ini batu pecah diambil dari desa Lingut OKUT dan daerah Lahat. Dari 2 lokasi material yang digunakan, nilai dari komponen untuk AC WC terdapat perbedaan tetapi memenuhi standar yang disyaratkan diantaranya nilai kadar aspal optimum 6,00 \% dan Bulk Density Standar 2,269 (gg/cc) untuk lokasi desa Lingut OKUT, sedangkan untuk lokasi Kota Lahan dan sekitarnya kadar aspal optimum 5,92 \% dan bulk Density Standar 2,270 (gg/cc). Perbedaan yang terjadi dikarenakan sumber batu ada yang berasal dari bukit (di darat) dan ada yang berasal dari dalam sungai.
\end{abstract}

Kata Kunci---Batu Lingut, Batu Lahat, AC- WC, Kadar Aspal Optimum, Bulk Density Standar

\section{PENDAHULUAN}

Aspal Beton merupakan salah satu jenis dari lapis perkerasan konstruksi perkerasan lentur. Campuran beton aspal tersebut terdiri atas agregat kasar, agregar halus, filler dan menggunakan aspal sebagai bahan pegikat. Filler yang biasa disebut juga bahan pengisi dapat diperoleh dari hasil pemecahan batuan secara alami maupun buatan.

Dalam rangka memenuhi kebutuhan material untuk pembuatan aspal beton jenis SC WC sumber material sangat menentukan. Sumber material yang digunakan untuk kebutuhan pembuatan aspal beton jenis AC WC ada yang didatangkan dari luar daearah sumsel yaitu batu pecah dari merak dan ada juga yang bersumber dari dalam sumatera sendiri yaitu batu ex Lahat kabupaten Lahat, ex Lingut kabupaten OKUT dan ex Martapura OKUS.

Dari data yang didapat bersumber berbagai JMF berbagai kegiatan proyek, hasil yang ada ditemukan perbedaan signifikan terutama nilai
Berat Jenis AC WC dari dua sumber yang dijelaskan yaitu, batu pecah dan abu batu ex Lingut kabupaten OKUT dan ex Lahat. Dengan adanya perbedaan yang signifikan maka sangat mempengaruhi volume $\mathrm{AC}$ WC yang akan digunakan dalam proyek yang akan dilaksanakan.

\section{KAJIAN PUSTAKA}

\section{A. Asphalt Beton (AC WC)}

Dalam [1] Aspal Beton merupakan salah satu jenis dari lapis perkerasan konstruksi perkerasan lentur. Jenis perkerasan ini merupakan campuran merata antara agregat dan aspal sebagai bahan pengikat pada suhu tertentu. Konstruksi perkerasan lentur terdiri dari lapisan-lapisan yang diletakkan diatas tanah dasar yang telah dipadatkan. Lapisanlapisan tersebut berfungsi untuk menerima beban lalu lintas dan menyebarkannya ke lapisan dibawahnya. 


\section{B. Campuran Beton Aspal (AC WC)}

Refrensi [2], persyaratan campuran Beton Aspal AC WC terdiri dari :

1) Agregat Kasar

Fraksi agregat kasar untuk rancangan adalah agregat yang tertahan saringan No. 8 $(2,36 \mathrm{~mm})$ dan haruslah bersih, keras, awet dan bebas dari lempung atau bahan yang tidak dikehendaki lainnya dan memenuhi ketentuan.

2) Agregat Halus

Agregat halus adalah agregat yang lolos saringan No. $8 \quad(2,36 \mathrm{~mm})$, yang harus memenuhi persyaratan agregat halus. Pasir yang boleh digunakan dalam campuran beraspal dengan presentase maksimum yang

diisyaratkan untuk Beton Aspal (AC) adalah $10 \%$.

3) Bahan Pengisi (filler)

Debu batu (stone dust) dan bahan pengisi yang ditambahkan harus kering dan bebas dari gumpalan-gumpalan dan bila diuji dengan penyaringan sesuai SNI 03-4142-1996 harus mengandung bahan yang lolos saringan No.200 (75 micron) tidak kurang dari $75 \%$ dari yang lolos saringan No.30 (600 micron). dan harus memenuhi gradasi

4) Bahan Pengikat (Aspal)

Refrensi [1] Aspal adalah material yang pada temperature ruang bersifat termoplastis serta aspal akan mencair jika dipanaskan sampai pada temperatur tertentu dan kembali membeku jika tempertaur turun. Bersama dengan agregat, aspal merupakan material pembentuk campuran perkerasan jalan. Banyaknya aspal dalam campuran perkerasan berkisar antara 4-10\% berdasarkan berat campuran atau $10-15 \%$ berdasarkan volume.

Fungsi aspal adalah sebagai bahan pengikat aspal dan agregat atau antara aspal itu sendiri, juga sebagai pengisi rongga pada agregat. Daya tahannya (durability) berupa kemampuan aspal mempertahankan sifat aspal akibat pengaruh cuaca dan tergantung pada sifat campuran aspal dan agregat. Sedangkan sifat adhesi dan kohesi yaitu kemampuan aspal mempertahankan ikatan yang baik. Sifat kepekaan terhadap temperaturnya aspal adalah material termoplastik yang bersifat lunak /cair apabila temperaturnya bertambah.

Aspal didefinisikan sebagai material berwarna hitam atau coklat tua, pada temperatur ruang berbentuk padat sampai agak padat. Jika dipanaskan sampai suatu temperatur tertentu aspal dapat menjadi lunak/cair sehingga dapat membungkus partikel agregat pada waktu pembuatan aspal beton atau dapat masuk ke dalam pori-pori yang ada pada penyemprotan /penyiraman pada perkerasan macadam maupun pelaburan.

Refrensi [3] Asphalt Institute (1997), campuran aspal beton yang baik diharapkan mampu melayani dengan baik variasi pembebanan selama bertahun-tahun dan akibat pengaruh kondisi lingkungan, serta diharapkan dari campuran aspal beton memiliki sifat-sifat dasar campuran aspal meliputi stability, durability, impermeability, workability, flexibelity, fatique resistance, dan skid resistance.

Dalam [4] Jenis campuran aspal beton yang selanjutnya disebut AC terdiri dari tiga jenis campuran yaitu :

- Aspal Beton Lapis Aus (AC-WC), ukuran maksimum agregat masing-masing campuran adalah $19 \mathrm{~mm}$,

- Aspal Beton Lapis Antara (AC-BC) ukuran maksimum agregat masing-masing campuran adalah $25 \mathrm{~mm}$

- Aspal Beton Lapis Pondasi (AC-Base) dan ukuran maksimum agregat masing-masing campuran $37,5 \mathrm{~mm}$.

Laston (AC-WC) merupakan suatu lapisan permukaan paling atas dari struktur perkerasan jalan raya yang berhubungan langsung dengan roda kendaraan, mempunyai tekstur yang lebih halus dan mampu memberikan sumbangan daya dukung yang terukur serta berfungsi sebagai lapisan kedap air untuk melindungi konstruksi dibawahnya.

Refrensi [4] menyatakan agregat adalah kumpulan yang kolektif dari pada mineral seperti pasir, kerikil, dan batu yang dipecahkan. Agregat berdasarkan ukuran partikelnya dapat dibedakan menjadi agregat kasar, agregat halus dan filler. Komposisi campuran keseluruhan agregat tersebut ditentukan oleh gradasi. Gradasi agregat merupakan distribusi partikel-partikel agregat berdasarkan ukurannya yang saling mengisi dan membentuk suatu ikatan saling mengunci (interlocking) sehingga dapat mempengaruhi stabilitas perkerasan. Gradasi agregat pada dasarnya sangat mempengaruhi besarnya rongga antar butir yang akan menentukan stabilitas perekerasan dan memberikan kemudahan selama proses pelaksanaan. 


\section{METODOLOGI PENELITIAN}

\section{A. Lokasi dan Sampel Penelitian}

Lokasi Penelitian di AMP PT. Putra Gemilang Nikom OKUS. Sampel Penelitian adalah JMF AMP PT.Putra Gemilang Nikom dari sumber material batu pecah dari Crusser PT. Comba Mahaka Utama di Desa Lingut.

\section{B. Material}

Material yang digunakan untuk membuat JMF AC WC dalam penelitian ini bersumber dari dua tempa lokasi yaitu :

1) Quary Crusser PT. Comba Mahaka Utama di desa Lingut OKUT dengan material ;

- Batu pecah $1 / 1,1 / 2,2 / 3$ dan abu batu (filler)

- Pasir dari Quary Martapura OKUT

- Aspal berasal dari PT. Pertamina Palembang

2) Quary Crusser PT. Comba Mahaka Utama di Kota Lahat dengan material ;

- Batu pecah $1 / 1,1 / 2,2 / 3$ dan abu batu (filler)

- Pasir dari Quary Martapura OKUT

- Aspal berasal dari PT. Pertamina Palembang

\section{Peralatan}

Peralatan yang digunakan dalam penelitian ini adalah peralatan yang standar digunakan dalam pembuatan JMF yang ada di AMP PT.Putra Gemilang Nikom.

\section{Metode Penelitian}

Metode pengujian mengikuti prosedur pengujian marshall, AASHTO dan Bina Marga. Tahapan penelitian diawali dengan pemeriksaan sifat-sifat fisis agregat dan aspal, serta bahan yang digunakan adalah Agregat kasar, Agregat halus, Abu Batu (filer), Aspal penetrasi 60/70 produksi PT. Pertamina.

Refrensi [5] Perencanaan campuran laston lapis aus (AC-WC) dengan mengacu kepada spesifikasi teknis Bina Marga. Metode perendaman yang dilakukan yaitu metode perendamana menerus (continuous).

\section{E.Alur Penelitian}

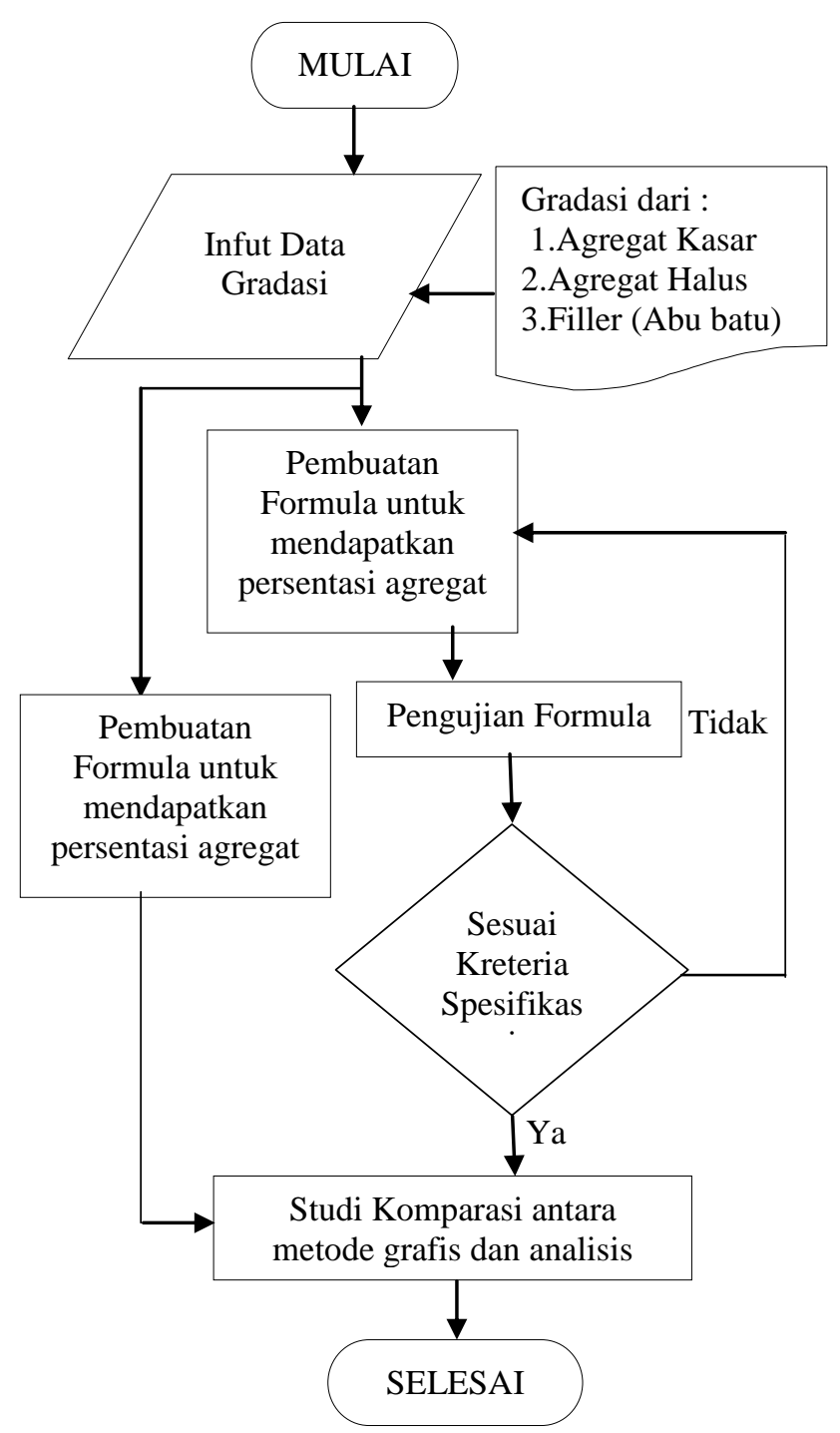

Gambar 1. Fowchat Penelitian

\section{HASIL PENGUJIAN DAN PEMBAHASAN}

\section{A. Hasil Rancangan AC WC Sumber Batu Pecah Desa Lingut OKUT}

Tabel 1. Hasil Uji Marshall Terhadap

Rancangan Campuran AC WC

\begin{tabular}{|c|l|c|c|}
\hline No & \multicolumn{1}{|c|}{ Jenis Uji } & $\begin{array}{c}\text { Hasil } \\
\text { Uji }\end{array}$ & Spec \\
\hline 1 & $\begin{array}{l}\text { Kadar Aspal } \\
\text { Optimum (\%) }\end{array}$ & 6,00 & - \\
\hline 2 & $\begin{array}{l}\text { Rasio Partikel } \\
\text { Ayakan 0,075 mm } \\
(\%) \text { dengan Kadar } \\
\text { Aspal Efektif (\%) }\end{array}$ & 1,05 & $0,62-1,2$ \\
\hline
\end{tabular}




\begin{tabular}{|c|c|c|c|}
\hline 3 & $\begin{array}{l}\text { Bulk Density } \\
\text { Standar (gg/cc) }\end{array}$ & 2,269 & - \\
\hline 4 & $\begin{array}{l}\text { Bulk Density PRD } \\
(\mathrm{gg} / \mathrm{cc})\end{array}$ & 2,317 & - \\
\hline 5 & VIM Standar (\%) & 4,50 & $3,0-5,0$ \\
\hline 6 & VIM Refusal & 2,47 & $\begin{array}{c}\text { Min.2,0 } \\
0\end{array}$ \\
\hline 7 & $\begin{array}{ll}\text { Prosen } & \text { Rongga } \\
\text { Terhadap } & \text { Agregat } \\
(\text { VMA })(\%) & \\
\end{array}$ & 17,51 & Min 15 \\
\hline 8 & $\begin{array}{l}\text { Prosen } \quad \text { Rongga } \\
\text { Terisi Aspal (\%) }\end{array}$ & 74,49 & Min. 65 \\
\hline 9 & $\begin{array}{l}\text { Stabilitas } \\
(\mathrm{kg})\end{array}$ & 1280 & Min.800 \\
\hline 10 & Kelelehan (mm) & 3,43 & $\begin{array}{l}2,00- \\
4,00\end{array}$ \\
\hline 11 & MQ (kg/mm) & 376 & - \\
\hline 12 & 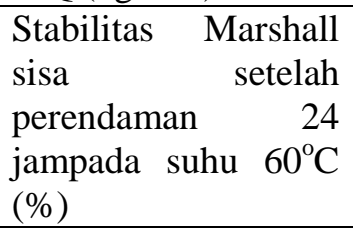 & 92,90 & Min 90 \\
\hline
\end{tabular}

Tabel 2. Komposisi AC WC Setelah Hasil Uji

Marshall Standar dan Kepadatan Mutlak

\begin{tabular}{|c|lc|r|}
\hline No & Uraian & $\begin{array}{c}\text { Proporsi } \\
\text { Campuran }\end{array}$ \\
\hline 1 & Kadar Aspal Optimum & $6,00 \%$ \\
\hline 2 & $\begin{array}{l}\text { Batu Pecah 19.00 } \mathrm{mm} \\
\text { (Split) }\end{array}$ & $9,45 \%$ \\
\hline 3 & $\begin{array}{l}\text { Batu Pecah 9.50 } \mathrm{mm} \\
\text { (Screen) }\end{array}$ & $35,60 \%$ \\
\hline 4 & Debu Batu (dust) & $42,34 \%$ \\
\hline 5 & Pasir (sand) & $4,71 \%$ \\
\hline 6 & Filler & $1,90 \%$ \\
\hline \multicolumn{3}{|r}{ Jumlah } & $100,00 \%$ \\
\hline
\end{tabular}

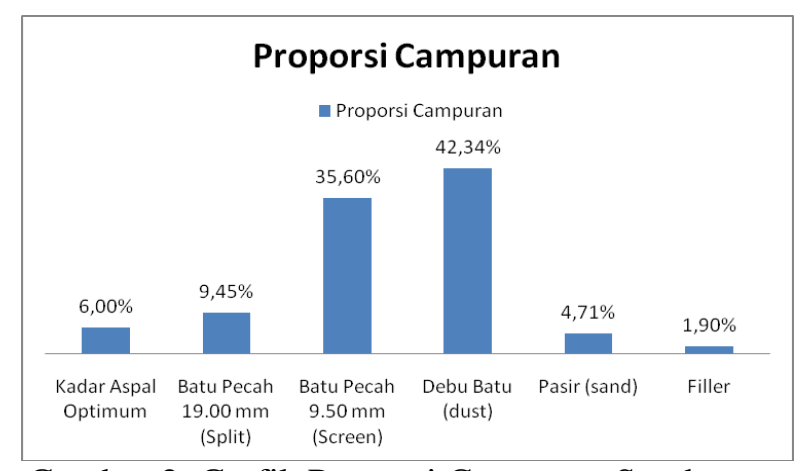

Gambar 2. Grafik Proporsi Campuran Sumber Batu Pecah Desa Lingut OKUT

\section{B. Hasil Rancangan AC WC Sumber Batu Pecah Desa Gunung Batu OKUS}

Tabel 3. Hasil Uji Marshall Terhadap Rancangan Campuran AC WC

\begin{tabular}{|c|c|c|c|}
\hline No & Jenis Uji & $\begin{array}{c}\text { Hasil } \\
\text { Uji }\end{array}$ & Spec \\
\hline 1 & $\begin{array}{ll}\text { Kadar } & \text { Aspal } \\
\text { Optimum (\%) } & \end{array}$ & 5,92 & - \\
\hline 2 & $\begin{array}{l}\text { Rasio } \quad \text { Partikel } \\
\text { Ayakan } 0,075 \mathrm{~mm} \\
(\%) \text { dengan Kadar } \\
\text { Aspal Efektif }(\%)\end{array}$ & 1,02 & $0,62-1,2$ \\
\hline 3 & $\begin{array}{l}\text { Bulk Density } \\
\text { Standar (gg/cc) }\end{array}$ & 2,270 & - \\
\hline 4 & $\begin{array}{l}\text { Bulk Density PRD } \\
(\mathrm{gg} / \mathrm{cc})\end{array}$ & 2,320 & - \\
\hline 5 & VIM Standar (\%) & 4,50 & $3,0-5,0$ \\
\hline 6 & VIM Refusal & 2,45 & $\begin{array}{c}\text { Min.2,0 } \\
0\end{array}$ \\
\hline 7 & $\begin{array}{ll}\text { Prosen } & \text { Rongga } \\
\text { Terhadap } & \text { Agregat } \\
(\text { VMA)(\%) } & \\
\end{array}$ & 17,59 & Min 15 \\
\hline 8 & $\begin{array}{l}\text { Prosen } \quad \text { Rongga } \\
\text { Terisi Aspal (\%) }\end{array}$ & 74,50 & Min. 65 \\
\hline 9 & $\begin{array}{ll}\text { Stabilitas } & \text { Marshall } \\
(\mathrm{kg}) & \end{array}$ & 1279 & Min. 800 \\
\hline 10 & Kelelehan (mm) & 3,40 & $\begin{array}{c}2,00- \\
4,00\end{array}$ \\
\hline 11 & MQ (kg/mm) & 371 & - \\
\hline 12 & $\begin{array}{lr}\text { Stabilitas } & \text { Marshall } \\
\text { sisa } & \text { setelah } \\
\text { perendaman } & 24 \\
\text { jampada suhu } & 60^{\circ} \mathrm{C} \\
(\%) & \end{array}$ & 92,50 & Min 90 \\
\hline
\end{tabular}

Tabel 4. Komposisi AC WC Setelah Hasil Uji

Marshall Standar dan Kepadatan Mutlak

\begin{tabular}{|l|l|r|}
\hline No & \multicolumn{1}{|c|}{ Uraian } & \multicolumn{1}{|c|}{$\begin{array}{c}\text { Proporsi } \\
\text { Campuran }\end{array}$} \\
\hline 1 & Kadar Aspal Optimum & $5,92 \%$ \\
\hline 2 & Batu Pecah 19.00 mm (Split) & $9,41 \%$ \\
\hline 3 & $\begin{array}{l}\text { Batu Pecah 9.50 mm } \\
\text { (Screen) }\end{array}$ & $35,74 \%$ \\
\hline 4 & Debu Batu (dust) & $42,35 \%$ \\
\hline 5 & Pasir (sand) & $4,70 \%$ \\
\hline 6 & Filler & $1,88 \%$ \\
\hline \multicolumn{2}{|r|}{ Jumlah } & $100,00 \%$ \\
\hline & \\
\hline
\end{tabular}




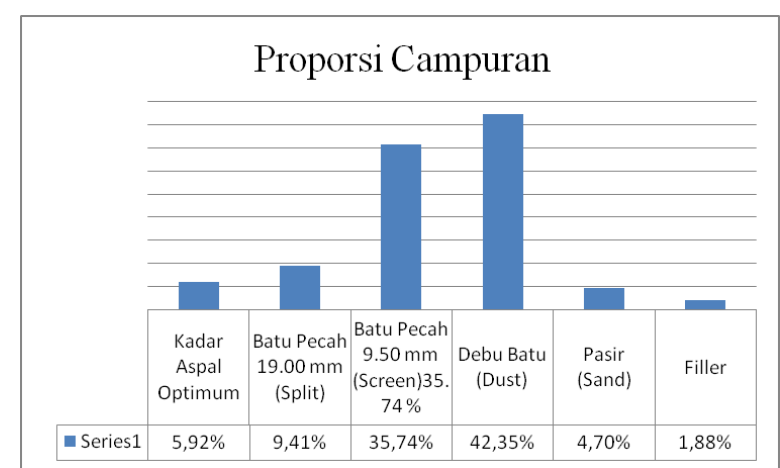

Gambar 3. Grafik Proporsi Campuran Sumber Batu Pecah Kota Lahat

Dari tabel 1 hasil uji Marshall terhadap rancangan campuran AC WC sumber batu pecah dan abu batu desa Lingut OKUT memenuhi spesifikasi teknik yang telah disyaratkan, dimana kadar aspal optimum 6,00 $\%$ dan Bulk Density standar dengan nilai 2,269 (gg/cc) nilai ini sangat penting dalam pelaksanaa di lapangan karena sangat mempengaruhi kualitas dan jumlah tonase kebutuhan dalam pelaksanaannya.

Dari tabel 3 hasil uji Marshall terhadap rancangan campuran AC WC sumber batu pecah dan abu batu Kota Lahat memenuhi spesifikasi teknik yang telah disyaratkan, dimana kadar aspal optimum 5,90 \% dan Bulk Density standar dengan nilai 2,270 (gg/cc). Bila dilihat dari hasil yang ada maka terdapat perbedaan antara sumber Desa Lingut OKUT dan sumber Kota Lahat hal ini dikarenakan sumber batu yang digunakan ada yang dari bukit (di darat) yang berasal dari desa Lingut dan ada sumber batu berasal dari dalam sungai yaitu Kota Lahat.

Dari tabel 1 dan gambar 2, tabel 4 dan gambar 3 komposisi AC WC Setelah hasil Uji Marshall Standar dan Kepadatan Mutlak terdapat perbedaan juga antara sumber material yang berasal dari desa Lingut OKUT dan Kota Lahat, hal ini juga disebabkan sumber batunya berbeda ada yang dari bukit (di darat) dan ada yang bersumber dari dalam sungai, tentunya hal ini sangat dipengaruhi oleh

kekerasan dan berat jenis material sangat berbeda.

\section{KESIMPULAN DAN SARAN}

\section{A. Kesimpulan}

1) Dari 2 lokasi material yang digunakan, nilai dari komponen untuk AC WC terdapat perbedaan tetapi memenuhi standar yang disyaratkan.

2) Perbedaan yang terjadi dikarenakan sumber batu ada yang berasal dari bukit (di darat) dan ada yang berasal dari dalam sungai.

\section{B. Saran}

1) Pelu adanya penelitian lebih lanjut dengan cara memvariasikan komposisi material diantaranya persentasi abu batu sebagai filler.

2) Perlu adanya penelitian lebih lanjut dengan kombinasi material dari ke dua daerah tersebut karena tempat desainnya di satu AMP.

\section{REFERENSI}

[1] Sukirman, S, 2003, Beton Aspal Campuran Panas, Penerbit Granit, Jakarta.

[2] Departemen Pekerjaan Umum, 2007, Rancangan Spesifikasi Umum Bidang Jalan dan Jembatan Divisi VI Perkerasan Beraspal, Edisi April 2007, Jakarta.

[3] Asphalt Institute 1997, Mix Design Methods For Asphalt Concrete And Other Hot-Mix Types (MS-2), vol. 6, pp. 141.

[4] Asrol, Sofyan M. Saleh, Muhammad Isya 2018, Karakteristik Campuran Aspal Beton AC WC dengan Substitusi Buton Rock Asphalt Terhadap Perendaman Air Lumpur Jurnal Arsip Rekayasa Sipil dan Perencanaan 1(3):39-45, DOI: 10.24815/jarsp.v1i1.11760

[5] Spesifikasi Teknis Perencanaan komposisi AC WC Metode Bina Marga 2010 revisi 3 (2018).Kementerian Pekerjaan Umum dan Perumahan Rakyat Direktorat Jenderal Bina Marga 2018, Jakarta 